\title{
Description of the supergiant isopod Bathynomus raksasa sp. nov. (Crustacea, Isopoda, Cirolanidae) from southern Java, the first record of the genus from Indonesia
}

\author{
Conni M. Sidabalok', Helen P.-S. Wong ${ }^{2}$, Peter K. L. $\mathrm{Ng}^{3}$ \\ I Division of Zoology, Research Center for Biology, Indonesian Institute of Sciences (LIPI), Gedung Widyasat- \\ waloka, Cibinong Science Center, Jl Raya Jakarta-Bogor Km 46, Cibinong 16911, Indonesia 2 St. John's Island \\ National Marine Laboratory, Tropical Marine Science Institute, National University of Singapore (NUS), 18 \\ Kent Ridge Road, 119227, Singapore 3 Lee Kong Chian Natural History Museum (LKCNHM), 2 Conserva- \\ tory Drive, National University of Singapore, Singapore 117377, Singapore
}

Corresponding author: Conni M. Sidabalok (sidabalok_conni@yahoo.com)

Academic editor: Tammy Horton | Received 4 May 2020 | Accepted 28 May 2020 | Published 8 July 2020

http://zoobank.org/1A80132D-D679-49C0-90D1-069770305473

Citation: Sidabalok CM, Wong HP-S, Ng PKL (2020) Description of the supergiant isopod Bathynomus raksasa sp. nov. (Crustacea, Isopoda, Cirolanidae) from southern Java, the first record of the genus from Indonesia. ZooKeys 947: 39-52. https://doi.org/10.3897/zookeys.947.53906

\begin{abstract}
The giant isopod genus Bathynomus A. Milne-Edwards, 1879, is recorded for the first time in Indonesian waters, from deep waters off southern Java in the Indian Ocean. Bathynomus raksasa sp. nov. is described and notes on juvenile specimens of an unidentified species found in the same locality are also provided. Bathynomus raksasa sp. nov. is characterized by the large size (averaging at $330 \mathrm{~mm}$ ), narrowly rounded clypeus apex, prominent longitudinal carina on the clypeus, convex lateral margins of the uropodal exopod and endopod, produced distolateral corners of the uropodal exopod and endopod which have acute ends, an uropodal exopod with a setal fringe of medium length (69\%), a pleotelson 1.6 times wider than long with the posterior margin medially concave, and the large number (11-13) of spines on the pleotelson.
\end{abstract}

\section{Keywords}

Bathynomus, Cirolanidae, Indian Ocean, Indonesia, new species, South Java, taxonomy

Copyright Conni M. Sidabalok et al. This is an open access article distributed under the terms of the Creative Commons Attribution License (CC BY 4.0), which permits unrestricted use, distribution, and reproduction in any medium, provided the original author and source are credited. 


\section{Introduction}

The genus Bathynomus A. Milne-Edwards, 1879 inhabits the deep sea in the Atlantic, Pacific and Indian Oceans, with some species reaching large sizes in excess of $30 \mathrm{~cm}$ length (Lowry and Dempsey 2006). Nineteen extant species are known in the genus (Bruce 1986, Magalhães and Young 2003, Lowry and Dempsey 2006, Boyko et al. 2008, Shipley et al. 2016, Kou et al. 2017).

Lowry and Dempsey (2006) revised the Indo-West Pacific taxa and recognized 16 species, of which seven were categorized as "supergiants"; species maturing above $150 \mathrm{~mm}$ and reaching $500 \mathrm{~mm}$ in length. Five "supergiant" species occur in the Indian and Pacific Oceans: Bathynomus lowryi Bruce \& Bussarawit, 2004 (Andaman Sea), B. crosnieri Lowry \& Dempsey, 2006 (Madagascar), B. keablei Lowry \& Dempsey, 2006 (India, Sri Lanka, Burma), B. kensleyi Lowry \& Dempsey, 2006 (Coral Sea, Philippines, South China Sea), and B. richeri Lowry \& Dempsey, 2006 (New Caledonia) (Lowry and Dempsey 2006). Two other "supergiant" species are known from the western Atlantic: B. giganteus A. Milne-Edwards, 1879, and B. miyarei Lemos de Castro, 1978 (Boyko et al. 2008). The new species described here adds another "supergiant" Bathynomus from the Indian Ocean to this list, and is the first from Indonesia.

\section{Material and methods}

The material was collected by the 2018 South Java Deep Sea Survey (SJADES 2018), a joint project between NUS and LIPI, with localities mostly in southern Sumatra and Java (Fig. 1). The terminology used and description format follows Lowry and Dempsey (2006).

The following acronyms are used: AM - Australian Museum, Sydney; LIPI - Lembaga Ilmu Pengetahuan Indonesia (Indonesian Institute of Sciences); MZB - Museum Zoologicum Bogoriense, Indonesia; NUS - National University of Singapore; SJADES - South Java Deep Sea Expedition; ZRC - Zoological Reference Collection of the Lee Kong Chian Natural History Museum, National University of Singapore.

\section{Taxonomy}

Suborder Cymothoida Wägele, 1989

Family Cirolanidae Dana, 1852

\section{Genus Bathynomus A. Milne-Edwards, 1879}

Restricted synonymy. A. Milne-Edwards, 1879: 21.— Bruce 1986: 126.— Kensley and Schotte 1989: 129._- Lowry and Dempsey 2006: 168. 


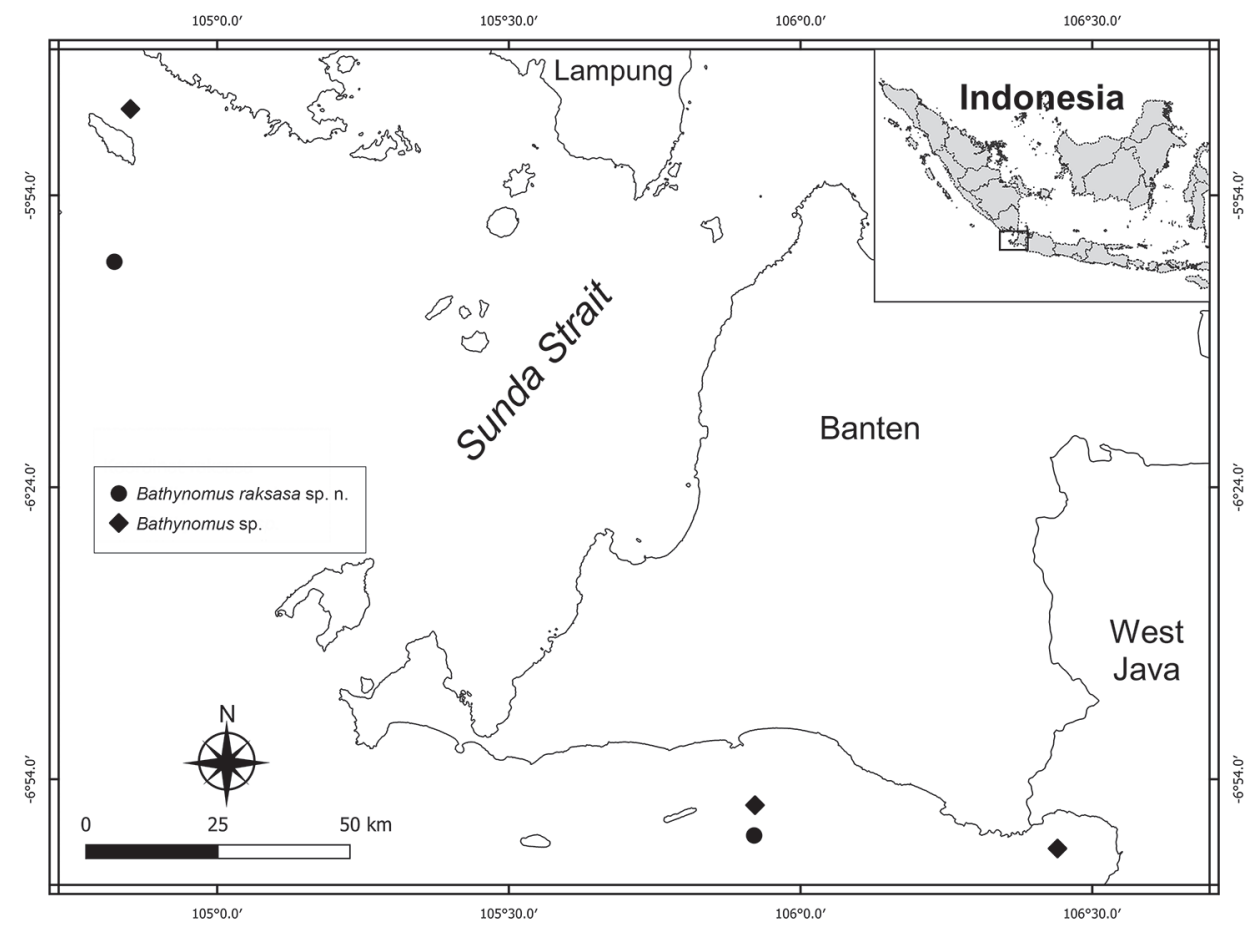

Figure I. Distribution of Bathynomus raksasa sp. nov. and Bathynomus sp. in Indonesian waters.

Remarks. The taxonomy of Bathynomus has been reviewed by Bruce (1986), Magalhães and Young (2003), with most recently by Lowry and Dempsey (2006). Two new species were added by Shipley et al. (2016) and Kou et al. (2017). The most recent review on Bathynomus fossils was done by Hyžný et al. (2019).

Type species. Bathynomus giganteus A. Milne-Edwards 1879; by monotypy.

\section{Bathynomus raksasa sp. nov.}

http://zoobank.org/84D71359-90FB-4CC6-856F-B96402F23211

Figs 2-5

Material examined. Holotype, male, $363 \mathrm{~mm}$; Indonesia, Sunda Strait (between Sumatra and Java); $6^{\circ} 00.828^{\prime} \mathrm{S}, 104^{\circ} 49.428^{\prime} \mathrm{E}$; 26 Mar. 2018; SJADES exped.; station CP 13, beam trawl 1259 m; MZB Cru.Iso 097. Paratype, female, 298 mm; Indonesia, Indian Ocean (East of Tinjil Island); 6 $59.778^{\circ} \mathrm{S}, 1^{\circ} 5^{\circ} 55.224^{\prime} \mathrm{E} ; 28$ Mar. 2018; SJADES exped.; station CP 28, beam trawl 957 m; ZRC 2020.0015.

Comparative material. Bathynomus giganteus A. Milne-Edwards, 1879 - 1 male, 354 mm; U.S.A., Virginia, 100 miles off Virginia Beach; 36.483N, 74.8W; 30 May 1962; 73 m depth; ZRC 2014.0837. Bathynomus doederleini Ortmann, 1894- 6 males, 
100, 120, 120, 128, 136, $145 \mathrm{~mm} ; 7$ females, 88, 90, 94, 130, 130, 138, $145 \mathrm{~mm} ; 3$ juveniles; Taiwan; AM P68684. 1 male, $125 \mathrm{~mm} ; 1$ female, 85 mm; 4 juveniles; Taiwan, Tashi port; 1990s; P. K. L. Ng leg.; deep-water; ZRC 1998.417. Bathynomus sp. - 1 subadult, not sexually mature, pereopod 7 not fully developed, $107 \mathrm{~mm}$; Indonesia, Indian Ocean (East of Tinjil Island); 656.664'S, 10555.315'E; 28 Mar. 2018; SJADES exped.; station CP 26, beam trawl 517 m; MZB Cru.Iso 098. 1 juvenile; Indonesia, Sunda Strait (between Tabuan Island and Sumatra); 5\%45.126'S, 104²51.080'E; 25 Mar. 2018; SJADES exped.; station CP 08, beam trawl 442 m; ZRC 2020.0016. 2 juveniles, 60, 63 mm; Indonesia, Indian Ocean (Pelabuhan Ratu Bay); $7^{\circ} 01.116$ 'S, 106 26.421'E; 3 Apr. 2018; SJADES exped.; station CP 55, beam trawl 379 m; ZRC 2020.0017.

Type-locality. Indonesia, Sunda Strait: between Sumatra and Java, $06^{\circ} 00.828^{\prime} S$, $104^{\circ} 49.428^{\prime} \mathrm{E}$.

Diagnosis. Narrowly rounded clypeus apex (Fig. 2C); prominent longitudinal carina on clypeus (Fig. 2C); convex lateral margins of uropodal exopod and endopod (Fig. 3D, E); produced distolateral corners of uropodal exopod and endopod with acute tips (Fig. 3D, E); uropodal exopod with medium-length setal fringe (69\%) (Fig. $3 \mathrm{D}, \mathrm{E})$; pleotelson 1.6 times wider than long with posterior margin medially concave (Fig. 2D); 11-13 spines on pleotelson (Fig. 2D).

Description of holotype male. Body (Fig. 2A) $363 \mathrm{~mm}$ long, $155 \mathrm{~mm}$ wide at pereonite 5, length 2.3 times width. Head (Fig. 2B) with ridge above eyes discontinuous; clypeus (Fig. 2C) with prominent longitudinal carina, distal margins slightly concave, apex narrowly rounded.

Antenna 2 (Fig. 2A, E) flagellum extending to end of pleonite 2.

Pereopod 1 (Fig. 3A) ischium with 2 posteroproximal robust setae, 2 robust setae on posterodistal margin; merus with 4 short robust setae on anterodistal angle, posterior margin with 4 robust setae in proximal row and 2 robust setae in distal row; propodus length 2.3 times width, with 5 robust setae on posterior margin. Pereopod 2 (Fig. 3B, C) ischium with 3 robust setae on posterior margin and 2 robust setae on posterodistal margin; merus with 7 short robust setae on anterodistal angle, posteromedial margin with 3 robust setae in proximal row and 2 robust setae in distal row; propodus with 4 robust setae on posterior margin. Pereopod 7 coxa (Fig. 2F) distally attenuated, curved posteriorly.

Pleonite 3 (Fig. 2F) not extending beyond pleonite 5.

Uropod (Figs 2D, 3D, E) not extending beyond pleotelson; peduncle with 3 robust setae; exopod and endopod with smooth lateral and distal margins; exopodal lateral margin convex with 10 robust setae along margin, setal fringe medium to continuous in length (69\%), medial margin straight, distomedial corner rounded, distal margin convex with 5 robust setae, distolateral corner slightly produced, acute; endopodal lateral margin convex, distally sinuate, with 4 robust setae; medial margin straight; distomedial corner rounded; distal margin straight with 11 robust setae; distolateral corner produced, acute.

Pleotelson (Fig. 2D) broader than long, 1.6 times as wide as length, posterior margin medially concave, smooth (minute pores), conspicuous longitudinal carina on 

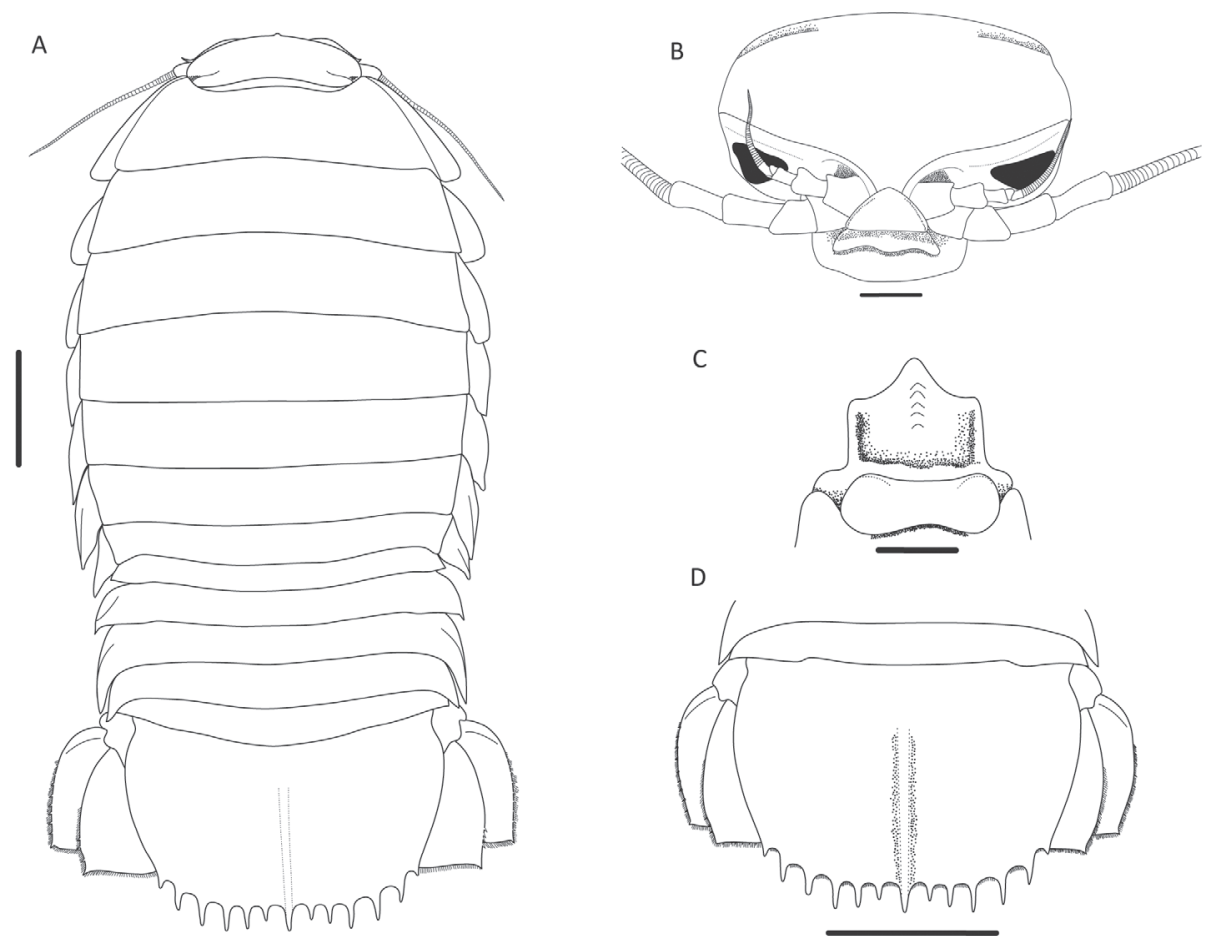

C

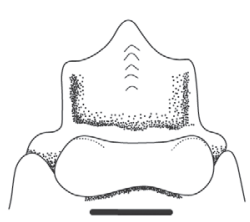

$\mathrm{D}$

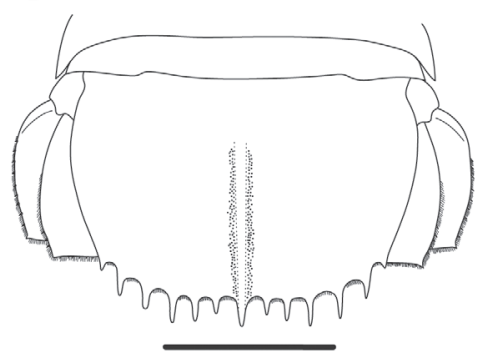

$\mathrm{E}$ $\mathrm{F}$

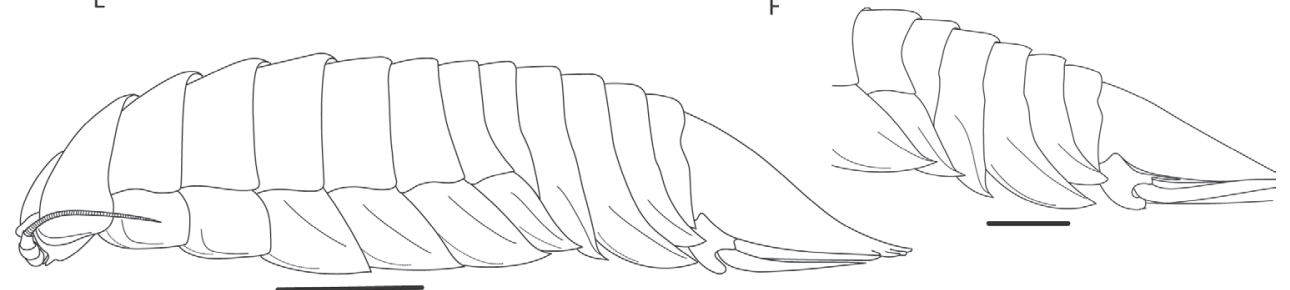

Figure 2. Bathynomus raksasa sp. nov., holotype male (363 mm) (MZB Cru.Iso 097), Indonesia A dorsal view $\mathbf{B}$ cephalon, anterior view $\mathbf{C}$ clypeal region $\mathbf{D}$ pleotelson $\mathbf{E}$ body, lateral view $\mathbf{F}$ pereon, lateral view. Scale bars: $5 \mathrm{~cm}(\mathbf{A}, \mathbf{D}, \mathbf{E}) ; 1 \mathrm{~cm}(\mathbf{B}, \mathbf{C}, \mathbf{F})$.

dorsal surface, with 11 distal and 2 lateral straight acute prominent spines along distal margin, without setae between spines, central distal spine simple.

Female. Similar to male.

Variation. Robust setae count on female as follows: exopodal lateral margin with 7-10 robust setae, distal margin with 4 or 5, endopodal lateral margin with 3-5 and distal margin with 8-10; pleotelson with 9 distal and 2 lateral straight acute prominent spines along distal margin.

Etymology. The epithet is the Indonesian word "raksasa" for giant, alluding to its enormous size and the significance of the find. The name is used as a noun in apposition. 

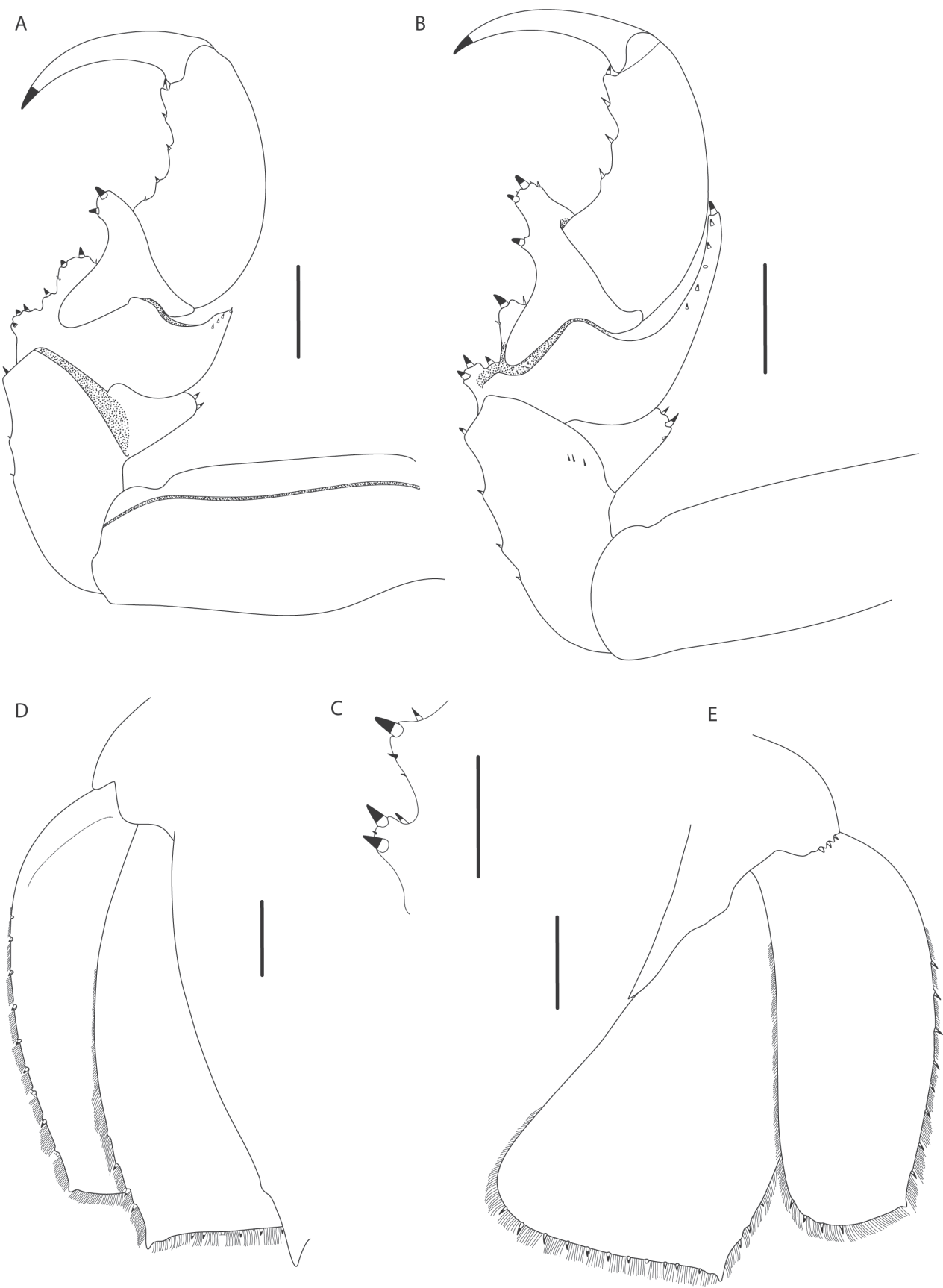

Figure 3. Bathynomus raksasa sp. nov., holotype male (363 mm) (MZB Cru.Iso 097), Indonesia A pereopod 1 B pereopod $2 \mathbf{C}$ pereopod 2 merus, posterolateral margin $\mathbf{D}$ uropod, ventral view $\mathbf{E}$ uropod, dorsal view. Scale bars: $1 \mathrm{~cm}(\mathbf{A}, \mathbf{B}, \mathbf{D}, \mathbf{E}) ; 0.5 \mathrm{~cm}(\mathbf{C})$. 
Remarks. Bathynomus raksasa sp. nov. can be readily identified by its large size (330 $\mathrm{mm}$ on average), narrowly rounded clypeus apex, produced and acute distolateral corners of uropodal rami, wider rather than long pleotelson with medially concave posterior margin and the presence of 11-13 pleotelson spines. Bathynomus raksasa sp. nov. is the sixth "supergiant" species from the Indo-West Pacific and is one of the largest known members of the genus.

In general appearance, B. raksasa sp. nov. is most similar to B. giganteus and B. lowryi. All three are large, averaging $300 \mathrm{~mm}$ in length, possess a prominent longitudinal carina on the dorsal surface of the pleotelson and have acute spines on the distal margin of the pleotelson. The new species is closest to B. giganteus, sharing the relatively medium length of antenna 2 (reaching to between the posterior of pereonite 2 and anterior of pereonite 3), lateral and posterior shape of the uropodal exopod and endopod, and the pleotelson spine count. Bathynomus raksasa sp. nov., however, differs markedly from $B$. giganteus by its more conspicuous longitudinal carina on the clypeus ventral surface (Fig. 4A) (vs. less conspicuous in B. giganteus; Fig. 4B), absence of a transverse carina on the anterior of the head (Fig. 4C) (vs. carina present in B. giganteus; Fig. 4D), the relatively shorter uropodal endopod ( 0.12 total body length, Fig. 4E) (vs. relatively longer, 0.15 body length in B. giganteus; Fig. 4F), the body surface, including that of the pleotelson, being covered with small low granules and smooth to the touch (Fig. 5A) (vs. granules more prominent and the surfaces distinctly rough in B. giganteus; Fig. 5B), the almost flat posterior ventral surface of the pleotelson (Fig. 5C) (vs. surface distinctly concave in B. giganteus; Fig. 5D), the straight spines of pleotelson (Fig. 5E) (vs. gently curved upwards in B. giganteus; Fig. 5F), the pleotelson is broader than long (Fig. 5A) (vs. as long as broad in B. giganteus, Fig. 5B), and the posterior margin of the pleotelson is broad and medially concave (Fig. 5A) (vs. broadly rounded in B. giganteus, Fig. 5B). Bathynomus raksasa sp. nov. can easily be distinguished from B. lowryi in possessing a relatively longer antenna 2 which reaches to the ends of pereonite 2 (vs. shorter antenna 2 which reaches only to the anterior part of pereonite 2 in $B$. lowryi), the narrowly rounded clypeus apex (vs. apex truncate in $B$. lowryi), straight pleotelson spines (vs. spines upwardly curved in $B$. lowryi) and the larger number (13) of robust setae on the pleotelson (vs. 9 in B. lowryi) (Bruce and Bussarawit 2004: figs 1, 6).

Bathynomus raksasa sp. nov. shares the same general uropodal exopod and endopod shape as B. crosnieri, B. kensleyi and B. richeri but can easily be distinguished from them in its possession of a conspicuous longitudinal carina on the dorsal surface of the pleotelson (Fig. 5A). Although the number of spines on the margin of the pleotelson (at least 11) is similar to those of B. crosnieri and B. richeri, the presence of the longitudinal ridge on the pleotelson easily separates $B$. raksasa sp. nov. from these species. Bathynomus raksasa sp. nov. also has the same number of spines on the margin of the pleotelson but can easily be distinguished from B. keablei in having the distolateral corners of the uropodal exopod and endopod distinctly produced (Fig. 3D, E) (vs. rounded and not produced in B. keablei; see Lowry and Dempsey 2006: fig. 17).

The appendix masculina is absent on the holotype male of B. raksasa sp. nov. (Fig. $5 \mathrm{G})$ but this is almost certainly not a species-character. It is known to be sometimes 


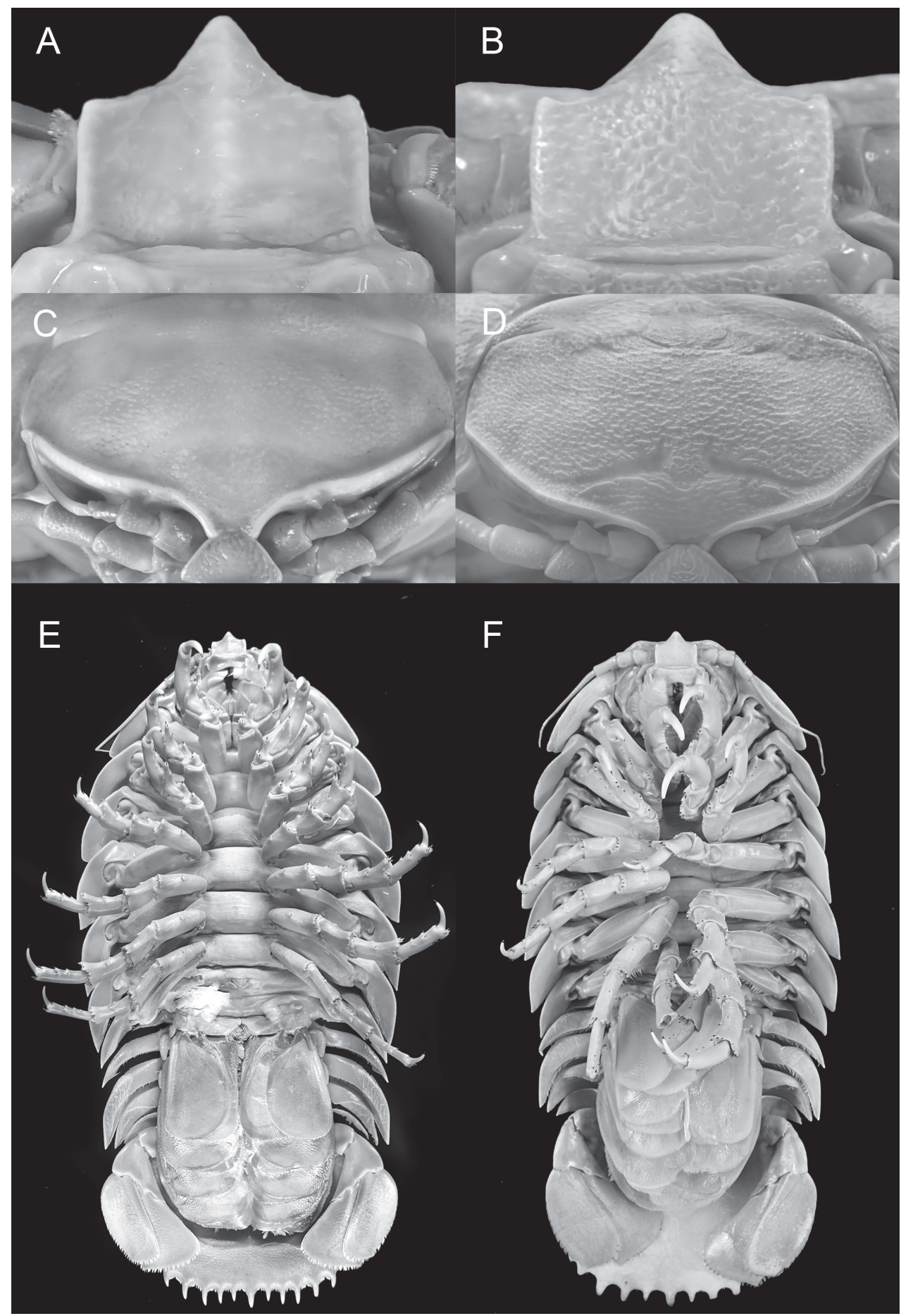

Figure 4. A, C, E Bathynomus raksasa sp. nov. holotype male (363 mm) (MZB Cru.Iso 097), Indonesia B, D, F B. giganteus male (354 mm) (ZRC 2014.0837), Caribbean A, B clypeus ventral surface C, D anterior of head $\mathbf{E}, \mathbf{F}$ body, ventral view. 
absent in $B$. doederleini from Taiwan (present study); with five out of seven males below the size of $130 \mathrm{~mm}$ lacking it. The largest males of $B$. doederleini $(136-145 \mathrm{~mm})$ possess appendix masculina. The absence or presence of appendix masculina has been previously used by Soong and Mok (1994) to determine the maturity of males of Bathynomus doederleini; "mature males" were males with appendix masculina and "maturing males" were those without appendix masculina and testes. Barradas-Ortiz et al. (2003) reported that some adult males of B. giganteus from Brazil (mostly smaller specimens below $290 \mathrm{~mm}$ ) lacked appendix masculina, especially in summer. They suggested that these smaller males might have been less reproductively active in summer and/or the appendix masculina may be a non-permanent organ which is lost or regrown when the animals moult (Barradas-Ortiz et al. 2003). Barradas-Ortiz et al. (2003) also noted that larger male specimens of $B$. giganteus tend to keep the organ for longer periods than smaller ones, although even large individuals $(310 \mathrm{~mm})$ sometimes do not possess the structure. We cannot be certain that either of the patterns above apply to $B$. raksasa sp. nov. as only one male was collected. The appendix masculina (Fig. $5 \mathrm{H})$ is present on the large male American specimen of B. giganteus (ZRC 2014.0837) examined here.

The SJADES cruise also obtained four juvenile and subadult specimens from southern Java (here identified as Bathynomus sp.) (Fig. 6) which we are unable to identify to the species level, especially as the diagnostic characters may not be developed. They are clearly not Bathynomus raksasa sp. nov. with a different pleotelson spination, shapes of pleotelson and uropodal rami. The largest specimen in the lot $(107 \mathrm{~mm})$ has an almost fully-developed pereopod 7 which indicates that the adult would not be too much larger in size. This, along with the presence of setae between the pleotelson spines, suggest that this species belongs to the "giant" group. The number of spines on the posterior margin of the pleotelson ranges between $5+2,7+2$ and $9+2$. Soong and Mok (1994) used the development of pereopod 7 as one of the characters to classify the development stages of Bathynomus doederleini. According to Soong and Mok (1994), individuals with "small, white" pereopod 7 and lacking either oostegites or penes and/ or appendix masculina were categorised as "subadult I" which equals to stage 2 of five development stages they proposed. However, we will not apply this approach to Bathynomus sp. because of the limited specimen number.

Bathynomus sp. superficially resembles the poorly known Bathynomus affinis Richardson, 1910, described from the Philippines from one specimen. There is, however, a problem with what has been identified as "Bathynomus affinis" by Lowry and Dempsey (2006: 169, figs 2, 3), who listed among their material, the type from the Philippines as well as two females from the Arafura Sea, providing figures of the latter. Bruce (1986: fig. 87A-E) had earlier figured the uropods, and pereopods 1 and 3 of the type specimen (sex not specified). The problem is that the distolateral corners of uropodal rami of the holotype from the Philippines is distinctly acute and curved (Bruce 1986: fig. 87A-C) whereas that of Lowry and Dempsey (2006: fig. 3D, E) from the Arafura Sea is distinctly wider and not produced. Significantly, Richardson's (1910: fig. 1) figures of the uropods are the same as those by Bruce (1986). The material from Arafura Sea are thus unlikely to be $B$. affinis s. str. 


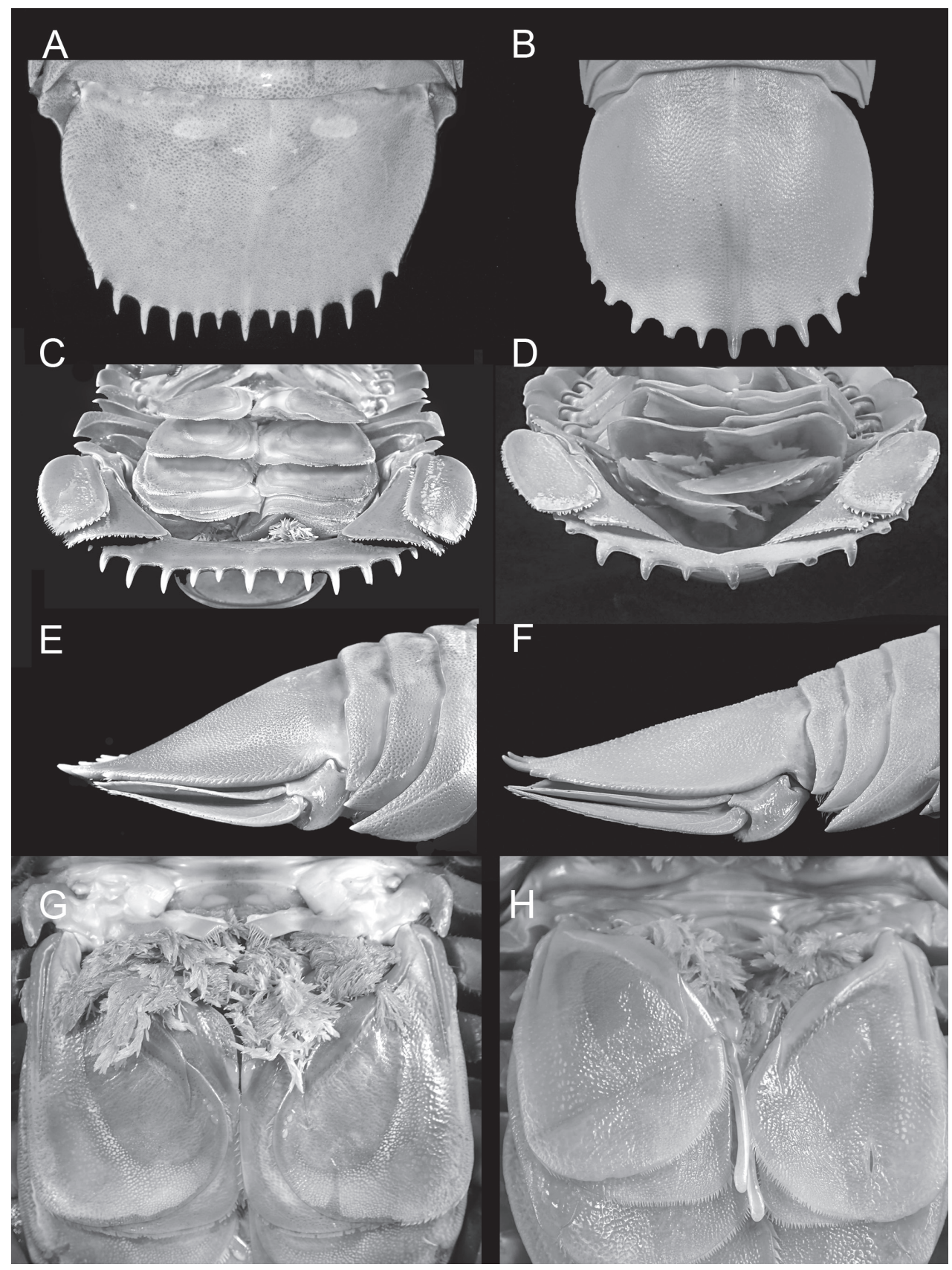

Figure 5. A, C, E, G Bathynomus raksasa sp. nov. holotype male (363 mm) (MZB Cru.Iso 097), Indonesia B, D, F, H B. giganteus male (354 mm) (ZRC 2014.0837), Caribbean A, B pleotelson dorsal view C, D pleotelson posterior view $\mathbf{E}, \mathbf{F}$ pleotelson lateral view $\mathbf{G}, \mathbf{H}$ pleopod 2. 
Our material of Bathynomus sp. from Java resembles the "B. affinis" of Lowry and Dempsey (2006) in possessing the same relative length of antenna 2 (reaching between pereonites 3 and 4), straight clypeus distal margins, the setal fringe on the uropodal exopod is long and continuous $( \pm 90 \%)$, and similar pleotelson spine count $(5+2,7+2$ and $9+2)$. The marked difference in the form of the uropodal endopod distolateral corner, however, indicates they are not conspecific. In addition, the uropod of Bathynomus sp. reaches to the end of the pleotelson (Fig. 6D) (vs. slightly extended beyond the pleotelson; Lowry and Dempsey 2006: fig. 2F) and the pleotelson central spine is weakly bifid (Fig. 6C) (vs. simple; Lowry and Dempsey 2006: fig. 2F). The uropods of our material from Java agree very well with the figures by Richardson (1910) and Bruce (1986), but until a complete redescription of the holotype of $B$. affinis is done and more character states are known, we are not certain if they are actually conspecific.

Bathynomus sp. differs from B. pelor Bruce, 1986 (from northwestern Australia) in having a longer antenna 2 that reaches to the middle of pereonite 4 (Fig. 6E) (vs. middle of pereonite 2; Bruce 1986: fig. 91A), weakly bifid pleotelson central spine (Fig. 6C) (vs. strongly bifid; Bruce 1986: fig. 91B), and the conspicuous longitudinal carina on the pleotelson (Fig. 6D) (vs. inconspicuous; Bruce 1986: fig. 91C). Both species share similar shape of uropodal rami with more acute and curved distolateral corner on the endopod of Bathynomus sp. (Fig. 6A, B) (vs. less acute and curved; Bruce 1986: fig. 91D). It differs from B. immanis Bruce, 1986, in the slightly concave lateral of uropodal exopod (Fig. 6A, B) (vs. strongly concave; Bruce 1986: fig. 90C, D), greater length of fringing setae $( \pm 80 \%$ ) on the lateral uropod exopod (Fig. 6A, B) (vs. 66\%; Bruce 1986: fig. 90C, D) and the weakly bifid pleotelson central spine (Fig. 6C) (vs. simple; Bruce 1986: fig. 89 D). The two species together with B. doederleini share similar uropodal endopod shapes (Fig. 6A, B).

Bathynomus sp. shares with B. kapala Griffin, 1975 (from Australia) a similar bifid central pleotelson spine but can easily be distinguished by its relatively longer antenna 2 (Fig. 6E) (middle of pereonite 4 vs. within pereonite 3; Lowry and Dempsey 2006: fig. 14 C), the straight head ridge (Fig. 6F) (vs. curved; Lowry and Dempsey 2006: fig. 14 D), a narrowly rounded clypeus apex (6G) (vs. broadly rounded; Lowry and Dempsey 2006: fig. $14 \mathrm{E}$ ), with only one row of fringing setae on the anterior margin of the basis of pereopod 7 (Fig. 6H) (vs. with two rows; Lowry and Dempsey 2006: fig. $23 \mathrm{~F}$ ) and the uropodal endopod distolateral margin is subacute and only slightly produced (Fig. 6A, B) (vs. not produced; Lowry and Dempsey 2006: fig. 15 D, E).

Compared to $B$. doederleini, Bathynomus sp. has pereopod 7 coxa more slender (Fig. 6I) (vs. relatively broader; Lowry and Dempsey 2006: fig. 10B), there is one row of fringing setae on the anterior margin of the basis of pereopod 7 (Fig. 6H) (vs. with two rows; Lowry and Dempsey 2006: fig. 23D), and the lengths of the pleotelson spines are similarly sized (Fig. 6D) (vs. uneven; Lowry and Dempsey 2006: fig. 10F).

Distribution. Sunda Strait and Indian Ocean, South Java, Indonesia; at depths of 957-1259 m. 


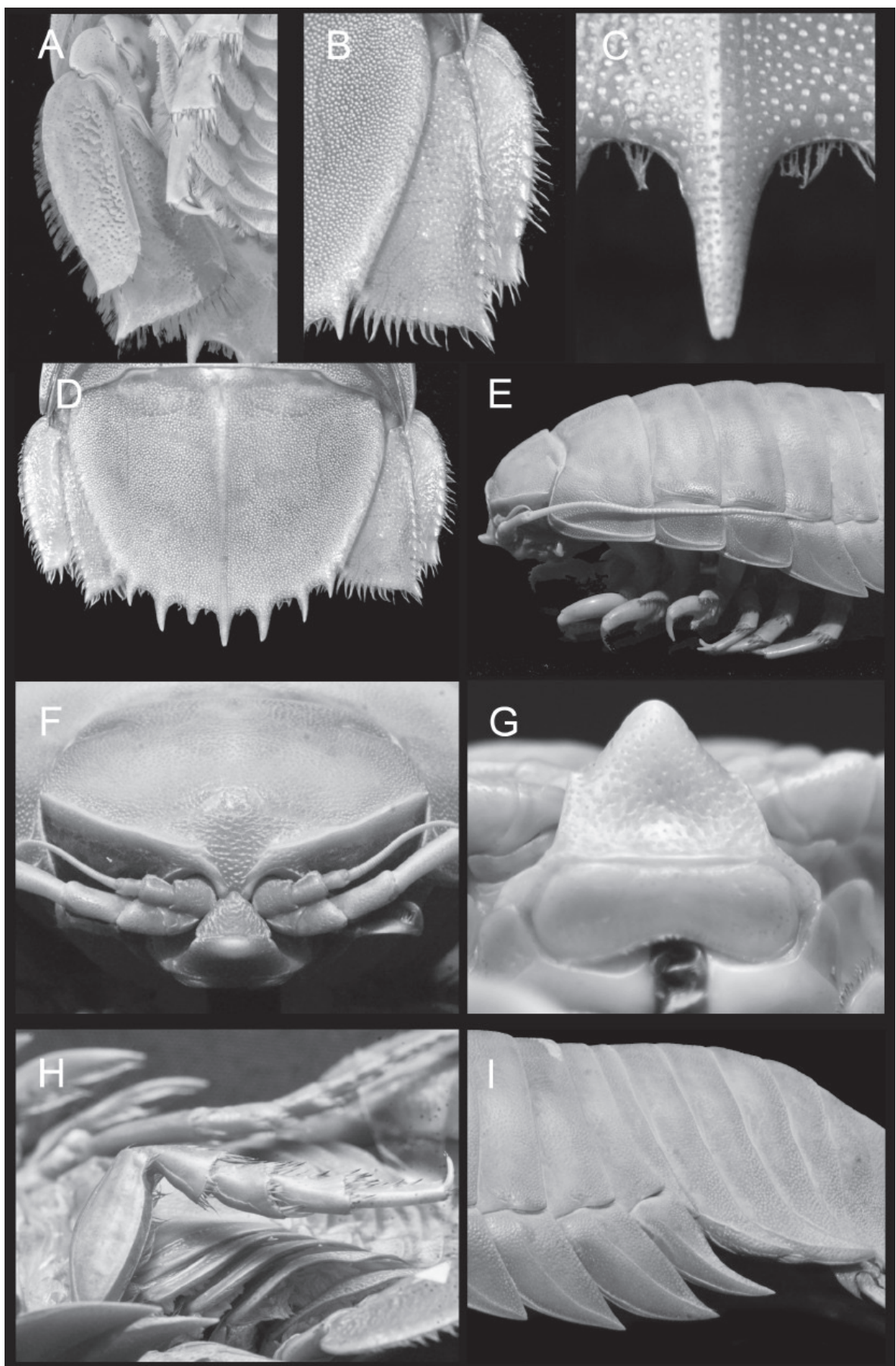

Figure 6. Bathynomus sp. (107 mm) (MZB Cru.Iso 098), Indonesia A uropod, ventral view B uropod, dorsal view $\mathbf{C}$ pleotelson central spine $\mathbf{D}$ pleotelson $\mathbf{E}$ length of antenna $2 \mathbf{F}$ cephalon, anterior view G clypeal region $\mathbf{H}$ pereopod 7 , ventral view I pereopod 7 coxa. 


\section{Acknowledgements}

The SJADES cruise (chief scientists: Dwi Listyo Rahayu and Peter Ng) was a joint Indonesian-Singapore expedition to southern Java funded by the National University of Singapore and the Research Center for Oceanography, Indonesian Institute of Sciences (LIPI); and supported by their respective Ministries of Foreign Affairs under the RISING 50 program to promote bilateral co-operation. Thanks are also due to Bertrand Richer de Forges and Chan Tin-Yam for their invaluable help in the trawling work and other support. We thank Farid Rifaie and Arid of Research Center for Biology LIPI for the map and some of the photos, respectively. Rene Ong and Muhammad Dzaki Bin Safaruan of LKCNHM are also thanked for assisting us with the photography set up and visits to the collections in LCKNHM. We are also grateful to the reviewers for their constructive comments which significantly improved the quality of this paper.

\section{References}

Barradas-Ortiz C, Briones-Fourzán P, Lozano-Álvarez E (2003) Seasonal reproduction and feeding ecology of giant isopods Bathynomus giganteus from the continental slope of the Yucatan peninsula. Deep Sea Research Part I: Oceanographic Research Papers 50: 495513. https://doi.org/10.1016/S0967-0637(03)00036-0

Boyko CB, Bruce NL, Hadfield KA, Merrin KL, Ota Y, Poore GCB, Taiti S, Schotte M, Wilson GDF (2008) World Marine, Freshwater and Terrestrial Isopod Crustaceans database. Bathynomus A. Milne-Edwards, 1879. http://www.marinespecies.org/isopoda/aphia. php? $\mathrm{p}=$ taxdetails\&id $=248508$ [Accessed on 2020-03-08]

Bruce NL (1986) Cirolanidae (Crustacea: Isopoda) of Australia. Records of the Australian Museum, Supplement 6: 1-239. https://doi.org/10.3853/j.0812-7387.6.1986.98

Bruce NL, Bussarawit S (2004) Bathynomus lowryi sp. nov. (Crustacea: Isopoda: Cirolanidae), the first record of the 'giant' marine isopod genus from Thailand waters. Phuket Marine Biological Center, Research Bulletin 65: 1-8.

Dana JD (1852) On the classification of the Crustacea Choristopoda or Tetradecapoda. American Journal of Sciences and Arts 2: 297-316. https://doi.org/10.5962/bhl.title.61409

Griffin DJG (1975) A new giant deep water isopod of the genus Bathynomus (Flabellifera: Cirolanidae). Proceedings of the Linnean Society of New South Wales 100: 103-109.

Hyžný M, Pasini G, Garassino A (2019). Supergiants in Europe: on the cirolanid isopod Bathynomus A. Milne Edwards [sic], 1879 (Malacostraca, Peracarida) from the Plio-Pleistocene of Italy. Neues Jahrbuch für Geologie und Paläontologie-Abhandlungen 291(3): 283-298. https://doi.org/10.1127/njgpa/2019/0802

Kensley B, Schotte M (1989) Guide to the Marine Isopod Crustaceans of the Caribbean. Smithsonian Institution Press, Washington, D.C. \& London, 1-308 pp. https://doi. org/10.5962/bhl.title.10375 
Kou Q, Chen J, Li X, He L, Wang Y (2017) New species of the giant deep-sea isopod genus Bathynomus (Crustacea, Isopoda, Cirolanidae) from Hainan Island, South China Sea. Integrative Zoology 12: 283-291. https://doi.org/10.1111/1749-4877.12256

Lemos de Castro A (1978) Descriçao de uma espécie nova gigante do gênero Bathynomus Milne Edwards [sic] do litoral Brasiliero (Isopoda, Cirolanidae). Revista Brasiliera de Biologia 38: $37-44$.

Lowry JK, Dempsey K (2006) The giant deep-sea scavenger genus Bathynomus (Crustacea, Isopoda, Cirolanidae) in the Indo-West Pacific. In: Richer De Forges B, Justine J-L (Eds) Tropical Deep-Sea Benthos, volume 24. Mémoires du Muséum national d'Histoire naturelle 193: 163-192.

Magalhães N, Young PS (2003) Bathynomus A. Milne Edwards [sic], 1879 (Isopoda, Cirolanidae) from the Brazilian coast, with description of a new species. Arquivos do Museu Nacional, Rio de Janeiro 61: 221-239.

Milne-Edwards A (1879) Sur un isopode gigantesque des grandes profondeurs de la mer. Comptes Rendus de l'Académie des Sciences, Paris 88: 21-23. https://doi.org/10.3406/ crai.1879.68524

Ortmann A (1894) A new species of the isopod-genus Bathynomus. Proceedings of the National Academy of Science, Philadelphia 1894: 191-193.

Richardson H (1910) Marine isopods collected in the Philippines by the U.S. Fisheries steamer Albatross in 1907-08. Bureau of Fisheries Document 736: 1-44.

Shipley ON, Bruce NL, Violich M, Baco A, Morgan N, Rawlins S, Brooks EJ (2016) A new species of Bathynomus Milne Edwards [sic], 1879 (Isopoda: Cirolanidae) from The Bahamas, Western Atlantic. Zootaxa 4147: 82-88. https://doi.org/10.11646/zootaxa.4147.1.6

Soong K, Mok H-K (1994) Size and maturity stage observations of the deep-sea isopod Bathynomus doederleini Ortmann, 1894 (Flabellifera: Cirolanidae), in eastern Taiwan. Journal of Crustacean Biology 14: 72-79. https://doi.org/10.2307/1549056

Wägele J-W (1989) Evolution und phylogenetisches System der Isopoda. Stand der Forschung und neue Erkenntnisse. Zoologica 140: 1-262. 